\title{
A case study exploring the impact on family life of two genetic conditions - severe haemophilia A and sickle cell disease
}

Anica Phillott

Sickle cell disease and haemophilia are rare inherited disorders that require intensive management. Few cases of people with both disorders have been reported. This case study describes the impact of living with these disorders and coping with their management on a boy and his mother.

Keywords: Haemophilia A, sickle cell disease, ethnic minority group, social care, housing, language skills

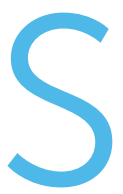

ickle cell disease (SCD) causes the synthesis of an abnormal haemoglobin molecule, resulting in deformation of erythrocytes and complications including anaemia, multiorgan damage and episodic pain (see Box 1) ${ }^{[1,2]}$. It is the most common disorder arising from a single gene mutation, and occurs mostly among people of African, Middle Eastern and South Asian origin. It is believed that between 12,000 and 15,000 people in the UK are living with $S C D$, of whom about half are in the Greater London area ${ }^{[3]}$. It is therefore more prevalent in the UK than haemophilia (there are about

ANICA PHILLOTT

Paediatric Haemophilia Nurse Manager and Specialist, Evelina London Children's Hospital, Guy's and St Thomas' NHS Foundation Trust, London, UK

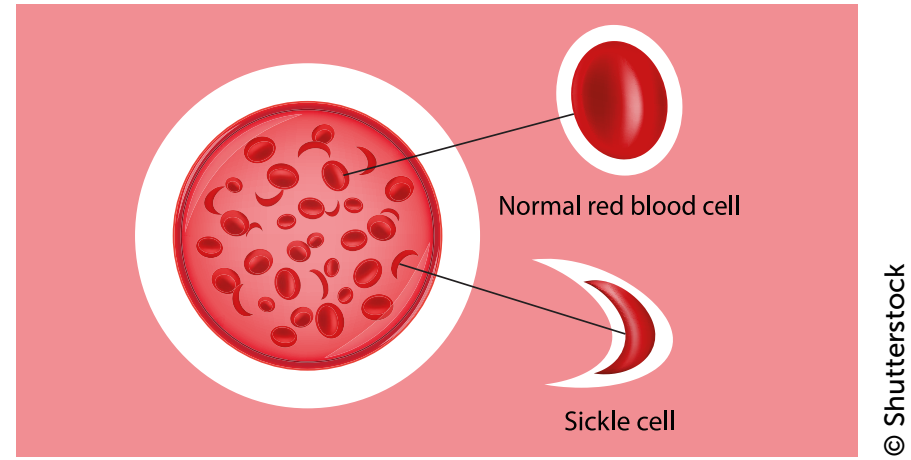

Sickle cell disease (SCD) is the most common disorder arising from a single gene mutation, and requires intensive management to retain quality of life and minimise long-term complications. The impact of SCD and haemophilia together has significant implications for lifelong treatment burden

6,000 people in the UK with haemophilia A and about 1,200 with haemophilia $B$, excluding carriers) ${ }^{[4]}$. Cases are usually identified by routine screening in areas of high prevalence. SCD is associated with a high treatment burden (Table 1).

Signs and symptoms of SCD include swelling of the hands and feet, symptoms of anaemia, including fatigue or extreme tiredness, and jaundice. Over time, SCD can lead to complications such as infections, delayed growth, and episodes of pain known as pain crises. Treatment involves monthly blood transfusions, daily antibiotics to reduce the risk of infection, folate to counteract the risk of anaemia, and iron chelation therapy for transfusional iron overload.

This is an Open Access article distributed under the terms of the Creative Commons Attribution-NonCommercial-NoDerivs License (https://creativecommons.org/licenses/by-nc-nd/3.0/) which permits use and distribution in any medium, provided the original work is properly cited, the use is non-commercial, and no modifications or adaptations are made. Copyright is retained by the authors. 
SCD is a collective term for inherited blood disorders caused by the sickle mutation on the haemoglobin HBB gene ${ }^{[1]}$. Individuals who are homozygous (inheritance from both parents) develop an abnormal haemoglobin molecule (HbS); this causes the most severe form of SCD (designated HbSS), which is associated with anaemia. HbSS is also the most common type, accounting for $50-60 \%$ of people with SCD. There are several heterozygous forms (inherited from one parent) that combine the propensity for cell sickling with other haemoglobin abnormalities such as beta-thalassaemia. Heterozygous forms, known as sickle cell trait, are associated with less severe symptoms.

Sickle cells are erythrocytes that are morphed from the normal disc shape into a crescent shape due to polymerisation of the abnormal haemoglobin molecule. Polymerisation occurs when the cell is deoxygenated; this is reversed by oxygenation, but repeated cycles of polymerisation and depolymerisation eventually cause haemolysis. The sickle cell is inflexible and causes vascular occlusion, ischaemia and inflammation resulting in a wide range of effects in multiple organs. Episodic pain crisis is a frequent cause of admission and treatment with opioid analgesics, but chronic pain also occurs. Chronic complications are due to damage to large vessels and include cerebrovascular disease, pulmonary hypertension, priapism and retinopathy, and progressive multi-organ damage - for example, causing hyposplenism (and an increased risk of infection), renal failure, bone disease and liver damage.

SCD and haemophilia are both disorders for which intensive management is essential to preserve quality of life and minimise long-term complications. When they occur together, their impact is increased by the interaction of the pathophysiological changes associated with each disorder - for example, SCD is a prothrombotic disorder that may modify the frequency of spontaneous bleeding due to haemophilia. Having SCD and haemophilia also substantially increases the lifelong treatment burden. Several case studies have described individuals with both SCD (or associated disorders, including sickle cell trait) and haemophilia, each diagnosed after presenting with a bleeding event and with contrasting approaches to management (Table 2$)^{[5-9]}$. This report summarises the diagnosis and management of a boy with SCD and haemophilia A.

\section{CASE STUDY}

\section{Medical history}

Ade (not his real name) was born by Caesarean section in 2008 after a full-term gestation. His mother was 22 years old when Ade was born. She is of West African origin; there was no further information about the family history and no known history of SCD or bleeding disorders other than the mother's lifelong tendency for mild epistaxis.

Ade was diagnosed with SCD by routine screening at birth. His test results were:

- Homozygous sickle cell anaemia (HbSS)

- Normal variant haemoglobin (HbA2) 2.6\% (normal range $1.8-3.3 \%)$

- Foetal haemoglobin (HbF) 19.8\% (normal range 0.0 $1.5 \%)$

- Haemoglobin fraction assay: HbA absent, HbS predominant

Table 1. Treatment of sickle cell disease ${ }^{[1,2]}$

\begin{tabular}{|ll}
\hline PREVENTING INFECTION & - Daily penicillin V until at least five years old \\
& - Pneumococcal vaccination every five years from age two \\
\hline ANALGESIA & - NSAIDs \\
BLOOD TRANSFUSION & - Ppioids \\
& - Primary/secondary prevention of stroke every three to six weeks indefinitely \\
HYDROXYUREA & - Preoperative transfusion \\
\hline - Prevention of acute complications \\
- Primary stroke prevention \\
\hline
\end{tabular}


Table 2. Published case reports of patients with both sickle cell disease and haemophilia

\begin{tabular}{|c|c|c|}
\hline $\begin{array}{l}\text { AGE AT DIAGNOSIS / } \\
\text { REPORT }\end{array}$ & $\begin{array}{l}\text { DIAGNOSES AND } \\
\text { TREATMENT }\end{array}$ & HISTORY \\
\hline $\begin{array}{l}6-11^{[5]} \\
\text { (3 patients) }\end{array}$ & $\begin{array}{l}\text { Sickle cell trait* } \\
\text { Haemophilia A }\end{array}$ & $\begin{array}{l}\text { Bleed events, predominantly haemarthrosis, muscle haematomas, epistaxis, } \\
\text { gum bleeds, gastrointestinal haemorrhage and haematuria } \\
\text { Bleeding pattern similar to patients with haemophilia A only, but mean annual } \\
\text { bleeding episodes significantly lower in those with sickle cell trait ( } 31+/-5 \text { vs } \\
45+/-7 ; p=0.033 \text { ) }\end{array}$ \\
\hline $30^{[6]}$ & $\begin{array}{l}\text { Sickle cell anaemia } \\
\text { Haemophilia A (FVIII 28\%) }\end{array}$ & $\begin{array}{l}\text { Excessive bleeding following minor trauma in two maternal uncles } \\
\text { Profuse bleeding after tooth extraction led to SCD diagnosis and internal } \\
\text { haemorrhage after road traffic accident (1977) } \\
\text { Two traumatic haematomas and a dental } \\
\text { extraction treated with cryoprecipitate (1977-1986) } \\
\text { Haematoma after blunt trauma treated with desmopressin (1986) } \\
\text { Red cell transfusions for priapism (1989 and 1990) }\end{array}$ \\
\hline $15^{[7]}$ & $\begin{array}{l}\text { Sickle cell anaemia } \\
\text { Haemophilia B (FVIII } 51 \text { IU/ } \\
\text { ml, Factor IX 12\%) } \\
\text { Hepatitis B + ve \& C +ve } \\
\text { Prophylaxis with } \\
\text { recombinant Factor IX } \\
\text { since age } 9 ; 3-5 \text { infusions/ } \\
\text { year for bleeds }\end{array}$ & $\begin{array}{l}\text { Ten admissions before age two and five admissions in last } 13 \text { years for vasculo- } \\
\text { occlusive crises and febrile illness } \\
\text { Recurrent haemarthroses and mucosal bleeds due to active lifestyle }\end{array}$ \\
\hline $19^{[8]}$ & $\begin{array}{l}\text { Sickle cell disease/beta- } \\
\text { thalassaemia } \\
\text { Haemophilia A (FVIII <1\%) }\end{array}$ & $\begin{array}{l}\text { Father had beta-thalassemia trait, mother had sickle cell trait, sister was a beta- } \\
\text { thalassemia carrier. No history of bleeding disorders } \\
\text { SCD diagnosed when admitted with abdominal pain } \\
\text { Presented five months later after bleeding for six days post-dental extraction; } \\
\text { treated with tranexamic acid and fresh frozen plasma }\end{array}$ \\
\hline $1.0,2.5^{[9]}$ & $\begin{array}{l}\text { Sickle cell disease } \\
\text { Haemophilia A (FVIII <1\%) } \\
\text { (treatment not described) }\end{array}$ & $\begin{array}{l}\text { No family history of sickle cell anaemia, but both disorders inherited from the } \\
\text { mother } \\
\text { Presented with post-circumcision bleeding } \\
\text { No history of bleeding events }\end{array}$ \\
\hline
\end{tabular}

* Sickle cell trait occurs in individuals heterozygous for the SCD gene (ie they have inherited the gene from one affected parent); it is asymptomatic and associated with normal life expectancy

Severe haemophilia A was diagnosed at age 18 days, following an episode of uncontrolled bleeding after intramuscular injection of vitamin K. His factor VIII (FVIII) activity level was $<1 \%$; genetic testing identified the IVS-22 inversion. He had no target joints and was treated with on-demand factor replacement once in 2009 (haematoma on his head) and twice in 2010 (haematoma, buttock and fall causing pain in left knee). In May 2010, aged two, Ade began prophylaxis with FVIII. Routine monitoring detected the presence of a low titre inhibitor (2.5\%) after nine exposure days.

A Portacath was inserted and Ade was treated with the immune tolerance induction strategy then in use (75 IU/kg/day - this has since changed). This raised his
FVIII activity level to $0.7-2.6 \%$ and cleared the inhibitor after two months. However, transcranial doppler, carried out as part of routine monitoring of SCD, was at this time abnormal (suggesting intracranial vascular narrowing) and Ade began regular blood transfusions for primary prevention of stroke. Since that time, Ade's management of sickle cell disease has been uneventful and he has remained well with routine blood transfusion for stroke prevention.

It is not known how Ade's SCD will affect his haemophilia management (or vice versa), but the haemophilia team will continue to work closely with the SCD team, in particular during the transition to adult services, with the aim of identifying and resolving problems rapidly. 


\section{Social issues}

Ade's mother moved from West Africa to live in Paris for eight years before moving to the UK. She spoke French, but had limited English when Ade first presented. This impacted on her ability to fully understand what was expected of her as a mother with a child with two complex conditions - for example, when to ask for medical help on time, how to tell the hospital she could not attend an appointment, and how to reschedule an appointment in a timely way. She also experienced a lack of financial security and difficulty in securing the services she was entitled to, such as negotiating with the landlord from whom she rented her home. The hospital was able to assist with translation services. She knows little about Ade's father, who has been absent for most of Ade's life. Ade's maternal grandmother died five days after giving birth to his mother, who was an only child.

Ade's mother had little social support and raised him as a single parent. They were evicted from their home when he was three years old because she was unable to pay the rent. Social services helped with housing and benefits including acquiring temporary accommodation, before securing a council flat.

In 2011, Ade's mother requested that he be circumcised for cultural reasons. This presented a challenge to the clinical team: circumcision for nonmedical reasons is not funded by the National Health Service (NHS) and Ade's complex medical needs meant that he was at high risk of complications. The clinical team was concerned that his mother would proceed with circumcision outside the NHS, a process with potentially even greater risks. However, during discussions between the clinical team and Ade's mother, he developed phimosis. The circumcision was performed for this indication in January 2012. Cover was provided with FVIII $50 \mathrm{IU} / \mathrm{kg}$ and tranexamic acid $10 \mathrm{mg} / \mathrm{kg}$ IV preoperatively; there was no evidence of inhibitors. He received FVIII $25 \mathrm{IU} / \mathrm{kg} 12$ hours postoperatively. He did well postoperatively and was discharged after two days on daily FVIII $50 \mathrm{lU} / \mathrm{kg}$ before switching back to his normal prophylaxis regimen of
FVIII $30 \mathrm{IU} / \mathrm{kg}$ on alternate days plus oral tranexamic acid $25 \mathrm{mg} / \mathrm{kg}$ for seven days post-surgery.

After a total of six years' of use, the Portacath was becoming uncomfortable for Ade when being accessed. This triggered the need for peripheral training before the Portacath stopped working and had to be surgically removed, with profound implications for his management. Peripheral access training for his mother began in November 2016 and the Portacath was removed in March 2017. The procedure was covered with FVIII 46 IU/kg plus tranexamic acid $10 \mathrm{mg} / \mathrm{kg}$ preoperatively, $30 \mathrm{lU} / \mathrm{kg} 12$ hours postoperatively, then daily treatment of $30 \mathrm{lU} / \mathrm{kg}$ for two days before restoring alternate-day prophylaxis; plus oral tranexamic acid $25 \mathrm{mg} / \mathrm{kg}$ for seven days post-surgery. Ade's current treatment is summarised in Table 3. In June 2018, his 48hour FVIII trough activity level was $7.6 \%$. It is not known whether SCD affected haemophilia control.

\section{Impact on schooling}

During the first five years of his school life, Ade was often absent due to frequent hospital admissions for routine blood transfusion. The unpredictable and episodic nature of SCD pain crises and need for frequent hospital or GP visits made life difficult for the family. They sometimes encountered a lack of understanding in healthcare providers about the nature and management of pain crises and haemophilia. When he can attend, Ade is active at school: he has one physical education lesson per week, he goes swimming and he plays football and basketball in the playground. He has had no joint bleeds in the past 12 months. Emotionally, he is thriving and enjoying the same things as boys of a similar age. His school attendance has improved in the last two to three years.

\section{The outlook}

Social services have continued to provide for the family's needs in the community; there has been little interaction with health services, other than to provide information to support a housing application. Ade's

Table 3. Summary of Ade's treatment at age 10 (see text for details)

\begin{tabular}{ll} 
SEVERE HAEMOPHILIA A & FVIII prophylaxis $30 \mathrm{IU} / \mathrm{kg}$ (1250 units) on alternate days \\
\hline SICKLE CELL DISEASE & Chronic monthly blood transfusions \\
& Penicillin V $250 \mathrm{mg}$ twice daily \\
Folic acid $5 \mathrm{mg} /$ day \\
Deferiprone $360 \mathrm{mg}$ three times daily \\
Participating in a clinical trial comparing deferiprone versus desferrioxamine for the treatment of \\
transfusional iron overload
\end{tabular}


mother is now (as of 2018) fluent in English. She has developed social links with families from similar ethnicity and through the Haemophilia Society. She promptly seeks help when she needs it and manages Ade's haemophilia and SCD well with little support from health or allied professionals. For his age, Ade has a good understanding of his haemophilia, and he receives educational support during his clinic appointments with the multidisciplinary team.

Environmental factors such as cold air, wind and air pollution may exacerbate pain associated with SCD ${ }^{[2]}$. This can mean staying indoors to avoid provoking a pain crisis - something that reduces activity levels and therefore has the potential to impair joint strengthening in children. SCD crises can initially present in a very similar way to a joint bleed and are very painful, but it is not clear how best to help patients distinguish between the two to allow prompt treatment. Monthly blood transfusions have improved quality of life for children with SCD and have increased longevity, so that survival into old age is now the expectation for many, at least in wealthier economies ${ }^{[10,11]}$. However, this means they look forward to a future marred by organ damage and debility due to complications ${ }^{[1,2]}$. This outlook is in stark contrast to the increasingly promising future for most people with haemophilia who receive prophylaxis with clotting factor and physiotherapist support.

The haemophilia service begins to consider transition from paediatric to adult services between the ages of 12 and 13 . Children are somewhat reluctant to think about the implications of moving to adult services but this is not uncommon. It will be essential to deliver continuity of care and to ensure that services remain accessible to Ade and his mother. The transition service for young people with haemophilia or SCD has an excellent record and the service is confident it will provide a supportive transition to adult care.

\section{ACKNOWLEDGEMENTS}

Writing support was provided by Steve Chaplin, Haemnet.

The author has advised no interests that might be perceived as posing a conflict or bias. Informed consent has been obtained from the individuals reported in this case study.

\section{REFERENCES}

1. Ware RE, de Montalembert M, Tshilolo L, Abboud MR. Sickle cell disease. Lancet 2017; 390: 311-23.

2. Piel FB, Steinberg MH, Rees DC. Sickle cell disease. New Engl J Med 2017;376:1561-73.

3. Public Health England. NHS sickle cell and thalassaemia screening: data trends and performance analysis. Data report 2016 to 2017: trends and performance analysis. 2018. Available from https://www.gov.uk/government/uploads/ system/uploads/attachment_data/file/713120/SCT_data_ report_2016_to_2017.pdf (accessed 25 November 2018).

4. United Kingdom Haemophilia Centres Doctors Organisation. Bleeding disorder statistics for April 2015 to March 2016: a report from the UK National Haemophilia Database. 2016. Available from http://www.ukhcdo.org/wp-content/uploads/2017/03/ Bleeding-Disorder-Statistics-for-April-2015-to-March-2016-forUKHCDO-Website.pdf (accessed 25 November 2018).

5. Ahmed SG, Ibrahim UA, Kagu MB, Abjah UA. Does sickle cell trait reduce the frequency of spontaneous bleeds in severe haemophilia? J Haem Pract 2016; 3(2):1-5. doi: 10.17225/ jhp00083).

6. Glenn LD, Lovely RM, Goldsmith JC. Combined sickle cell anemia and mild hemophilia A: successful treatment of hemorrhage with DDAVP. Am J Hematol 1991;37:64.

7. Kumar M, Herring RA. Rare combination of homozygous sickle cell disease (Hb SS) and haemophilia B in a paediatric patient. Br J Haematol 1997:98:780-1.

8. Dhiman P, Chaudhary R, Sudha K. Sickle cell- $\beta$ thalassemia with concomitant hemophilia $A$ : a rare presentation. Blood Res 2015; 50: 264-7.

9. El Maataoui H, Fahi A, Oukkache B. Sickle cell trait and haemophilia: a rare association. Pan Afr Med J 2018; 29 : 92.

10. Gardner K, Douiri A, Drasar E, et al. Survival in adults with sickle cell disease in a high-income setting. Blood 2016; 128: 1436-8.

11. Lobo CLC, Nascimento EMD, Jesus LJC, et al. Mortality in children, adolescents and adults with sickle cell anemia in Rio de Janeiro, Brazil. Rev Bras Hematol Hemoter 2018; 40:37-42.

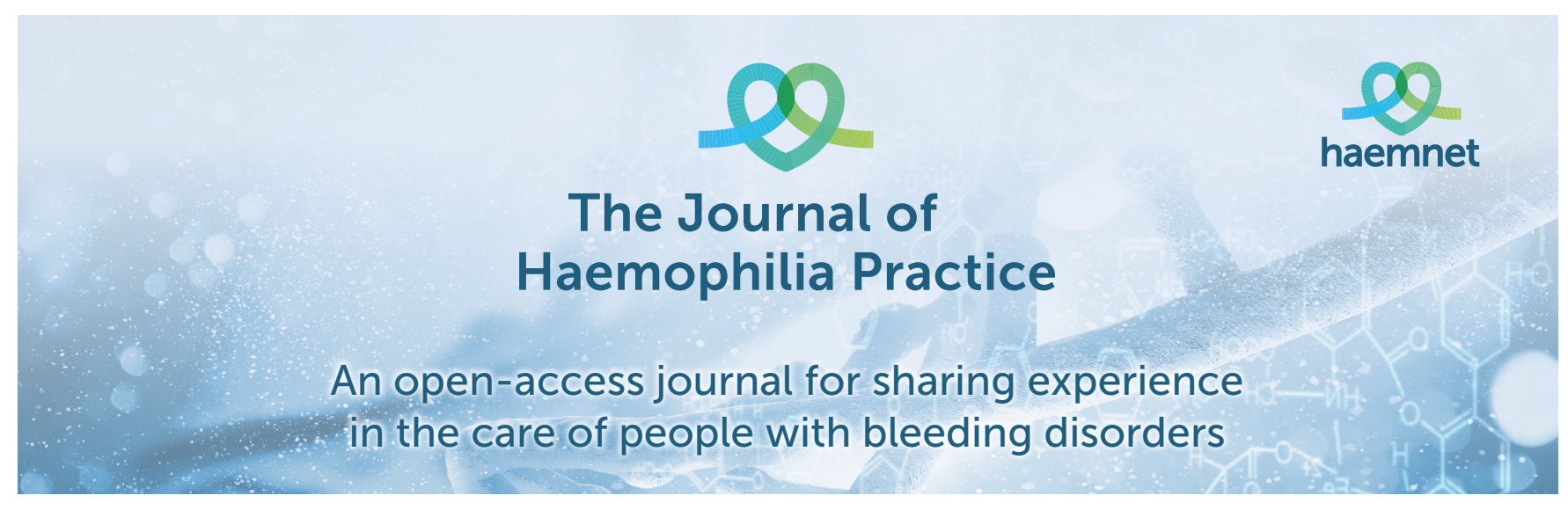

